\title{
Wettability of the Cotton and Polyester Fabrics Coated by Nanostructured Indium-doped Zinc Oxide Layers
}

\author{
N.P. Klochkoํㅛ I.V. Khrypunova ${ }^{1}$, K.S. Klepikova1,,* V.R. Kopach ${ }^{1}$, D.O. Zhadan ${ }^{1}$, S.I. Petrushenko², \\ S.V. Dukarov ${ }^{2}$, V.M. Lyubov ${ }^{1}$, M.V. Kirichenko ${ }^{1}$, A.L. Khrypunova ${ }^{1}$ \\ ${ }^{1}$ National Technical University "Kharkiv Polytechnic Institute”, 2, Kyrpychova St., 61002 Kharkiv, Ukraine \\ ${ }^{2}$ V.N. Karazin Kharkiv National University, 4, Svobody Square, 61022, Kharkiv, Ukraine
}

(Received 14 March 2021; revised manuscript received 15 April 2021; published online 20 April 2021)

\begin{abstract}
Indium-doped zinc oxide ( $\mathrm{ZnO}: \mathrm{In})$ thin films were deposited onto cotton (Ct) and polyester (PET) fabrics via Successive Ionic Layer Adsorption and Reaction (SILAR) method for the purpose of developing comfortable to wear, nontoxic, lightweight, and air-permeable textile. Thus, we obtained materials with hierarchical micro- and nanoscale roughness $\mathrm{ZnO}: \mathrm{In} / \mathrm{Ct}$ and $\mathrm{ZnO}: \mathrm{In} / \mathrm{PET}$, respectively. The obtained $\mathrm{ZnO}: \mathrm{In}$ films have a single-phase nanograined polycrystalline wurtzite hexagonal structure. It has been shown that the inherent cotton hydrophilicity provides wettability of $\mathrm{ZnO}: \mathrm{In} / \mathrm{Ct}$ fabric both before and after vacuum annealing. On the contrary, the $\mathrm{ZnO}: \mathrm{In} / \mathrm{PET}$ fabric is hydrophobic, its water contact angle $C A$ equals $140^{\circ}$. It turned out that it is possible to impart superhydrophobic properties to the $\mathrm{ZnO}: \mathrm{In} / \mathrm{PET}$ fabric without any additional impregnation layer by means of post-growth vacuum annealing at $200{ }^{\circ} \mathrm{C}$ for 1 or $2 \mathrm{~h}$. The superhydrophobicity of this fabric was confirmed via both static and dynamic measurements of $C A=160^{\circ}$ and contact angle hysteresis $C A H=10^{\circ}$, respectively. The Cassie-Baxter wetting state for the annealed $\mathrm{ZnO}$ :In/PET fabric is identified through a water-drop evaporation technique. Upon exposure to ultraviolet (UV) radiation ( $26 \mathrm{~W}$, wavelengths in the $315-400 \mathrm{~nm}$ range) for $60 \mathrm{~min}$, the vacuum annealed $\mathrm{ZnO}: \mathrm{In} / \mathrm{PET}$ fabrics are transformed from superhydrophobic to hydrophobic, their $C A s$ reduced from $160^{\circ}$ to $\sim 130^{\circ}$ and returned after 9 days of storage in the dark. Thus, we obtained a superhydrophobic fabric that remains non-wettable under operating conditions in sunlight.
\end{abstract}

Keywords: Indium-doped zinc oxide, Superhydrophobicity, Cotton, Polyester.

DOI: 10.21272/jnep.13(2).02036

PACS numbers: 81.16.Be, 68.55.ag, 68.08.De

\section{INTRODUCTION}

In the last few years, the innovation on fiber-based smart materials has increased substantiality because of demands for a comfortable and healthy life, which ask for a superhydrophobic textile, for instance, by mimicking the superhydrophobic lotus leaf in nature, the socalled "lotus effect" [1,2]. Thus, the search for materials with superhydrophobic surfaces has become the center of attention for many researchers [1-13]. The use of nanostructured zinc oxide $(\mathrm{ZnO})$ coatings for the functionalization of textile substrates is growing rapidly, since they can provide unique multifunctional properties together with superhydrophobicity, such as photocatalytic self-cleaning, antimicrobial activity, protecting against neurotoxicity, activation of body enzymes, attenuation of diabetic complications, protection against solar ultraviolet, flame retardancy, and thermal insulation [1,2-5,7]. Various research groups are studying not only nanostructured coatings of pure zinc oxide, but also of $\mathrm{ZnO}$ alloyed with different metals, for example, $\mathrm{ZnO}: \mathrm{Al}$ [9], $\mathrm{ZnO}: \mathrm{Mg}$ [2], etc. Mostly, $\mathrm{ZnO}$ nanoparticles are deposited on a given textile substrate as previously prepared colloidal solutions. In this way, thin hydrophobic layers were obtained via sol-gel method [2-4, 6], through dip-coating technique [4], or by dry cure padding [5]. In some works, hydrophobic coatings of pure or alloyed $\mathrm{ZnO}$ nanorods and other nanostructures are synthesized in situ using hydrothermal deposition [1, 9], pulsed electrodeposition [14], electroless deposition [8], etc. A common approach to the creation of all listed superhydrophobic $\mathrm{ZnO}$ coatings, except for [8], is a re- quired final chemical modification through processing with a fluoro-containing polymer or silane [7] in order to generate a low surface energy. According to [3], the "lotus effect" would not be achieved without the application of organic or inorganic-organic hybrid surface modification with alkyl or perfluoroalkyl functional groups. For example, to provide superhydrophobicity to $\mathrm{ZnO}$ nanorods in [6] and to the covered by $\mathrm{SiO}_{2}$ shells $\mathrm{ZnO}$ nanorods in [1], they were modified with octadecyltrimethoxysilane. In [3], $\mathrm{ZnO}$ nanorods were covered by a self-assembled monolayer of perfluorodecyltriethoxysilane. Authors [4] used a self-assembled stearic acid layer. In [5], the post-deposition modification of $\mathrm{ZnO}$ nanoparticle surfaces has been made with hexadecyltrimethoxysilane. However, silane monolayers can degrade and lose superhydrophobicity upon abrasion damages. At the same time, the accumulation of fluorine from fluoro-containing layers is dangerous for the environment due to their potential toxicity. Therefore, the possibility of rejecting these modifiers, which was demonstrated in [8] for a superhydrophobic coating of $\mathrm{ZnO}$ nanoparticles obtained via electroless deposition onto textile, is encouraging. As for the fabric substrate, authors [8] have chosen the most used in the textile industry polyester, namely polyethylene terephthalate (PET) fabrics. According to [7], PET fabrics themselves show poor wettability properties and hydrophobicity. As indicated in [6], an uncoated PET fabric, which contained PET fibers of diameter 9-10 $\mu \mathrm{m}$, demonstrated a water contact angle $(C A)$ obtained from an image of a sessile (static) drop on the horizontal surface $\sim 123^{\circ}$. Its water dynamic sliding angle $(S A)$, or the roll-off angle

\footnotetext{
* catherinakle@gmail.com
} 
$(\Delta \vartheta)$, which exceeds the maximum contact angle hysteresis $(C A H)$ without moving, is $\sim 15^{\circ}$ [6]. At the same time, according to [3], pristine PET fibers of diameter $20 \mu \mathrm{m}$ give $C A \approx 65^{\circ}$. In any case, the wettability of polyester is less than that of an uncoated cotton $(\mathrm{Ct})$ fabric, for which $C A \approx 0^{\circ}[2]$ due to the abundance of hydroxyl groups in the cellulose molecules that make up cotton. The electroless method for the deposition of $\mathrm{ZnO}$ nanoparticles on PET woven fabric with water $C A$ of $\sim 133^{\circ}$ that was used in [8] to obtain a superhydrophobic surface of the $\mathrm{ZnO} / \mathrm{PET}$ fabric with $C A$ of $150^{\circ}$ consists of three steps. According to [8], this catalytic/autocatalytic electroless $\mathrm{ZnO}$ deposition involves sensitization in a solution containing tin ions, activation in a solution containing palladium ions, and $\mathrm{ZnO}$ deposition from an aqueous solution of zinc nitrate $\left(\mathrm{Zn} \cdot\left(\mathrm{NO}_{3}\right)_{2}\right)$ and dimethylamineborane $\left(\left(\mathrm{CH}_{3}\right)_{2} \mathrm{NHBH}_{3}\right)$.

It was shown in our previous work [13], that due to the introduction of indium chloride $\left(\mathrm{InCl}_{3}\right)$ into an aqueous solution during deposition by Successive Ionic Layer Adsorption and Reaction (SILAR) method on glass substrates, it is possible to obtain indium-doped zinc oxide ( $\mathrm{ZnO} \mathrm{In}$ ) coatings in the form of nanorod arrays with pointed ends. According to $[6,11]$, such a form contributes to superhydrophobicity through the Cassie-Baxter model. In this work, we propose a simple, cheap and scalable SILAR method for the production of polyesterbased superhydrophobic textile by modifying PET with a nanocrystalline $\mathrm{ZnO}$ :In thin layer by avoiding the use of noble metals and without any additional impregnation layers. For this, a comparative analysis is carried out concerning the surface morphology, crystal structure, chemical composition and optical properties of nanostructured ZnO:In films, which were made by SILAR method on the surface of cotton and polyester fibers to obtain hierarchical structures with micro- and nanoscale roughness, $\mathrm{ZnO}: \mathrm{In} / \mathrm{Ct}$ and $\mathrm{ZnO}: \mathrm{In} / \mathrm{PET}$, respectively. In the study, the surface wettability of the textiles, in particular $\mathrm{ZnO}$ :In/PET fabric, was characterized by measuring not only static $C A$ as in $[2,8,9]$. The wetting mechanism for $\mathrm{ZnO}$ :In/PET fabric is observed through a water-drop evaporation technique [14]. We also analyzed the $C A H$, which is related to the material surface energy, by means of liquid dispensing and retracting method [11]. In accordance with [9, 11, 14], the dynamic tilt angle measurements were used to determine the ability of the obtained superhydrophobic material to self-cleaning. Then, we studied the influence of ultraviolet (UV) radiation on the $\mathrm{ZnO}: \mathrm{In} / \mathrm{PET}$ surface wetting to ascertain the possibility of using this superhydrophobic material at the terrestrial sunlight. The novelty of the current research work is a simple and cheap method for creating comfortable to wear, nontoxic, lightweight and air-permeable superhydrophobic ZnO:In/PET fabric without any surface modifications that remains nonwettable under operating conditions in sunlight.

\section{EXPERIMENTAL DETAILS}

\subsection{Deposition of ZnO:In Thin Films by SILAR Method onto Cotton and Polyester Fabrics to Obtain ZnO:In/Ct and ZnO:In/PET Textiles}

Before coating, clean fabric samples were boiled in distilled water for 15 min. Next, to ensure adhesion of $\mathrm{ZnO}$ :In with fabric, a seed layer was deposited by a dipcoating method. A seed solution contained zinc complex $\left(\mathrm{Zn}(\mathrm{NH} 3)_{4}{ }^{2+}\right.$ ) prepared by dissolving $0.05 \mathrm{M} \mathrm{ZnO}$ in $1 \mathrm{M}$ $\mathrm{NH}_{4} \mathrm{OH}$ aqueous solution. Then, a Ct or PET sample was dip-coated in the seed solution for $30 \mathrm{~s}$ and dried in a stream of hot air. This process was repeated 5-10 times to obtain $\mathrm{ZnO}$ seed particles, which coated the $\mathrm{Ct}$ or PET fabric surface uniformly. Subsequently, thin $\mathrm{ZnO}$ :In films were grown on the seeded $\mathrm{Ct}$ and PET fabrics using SILAR method. Deposition of ZnO:In thin films was carried out using an aqueous cationic precursor containing $120 \mathrm{mM}$ potassium zincate $\left(\mathrm{K}_{2} \mathrm{ZnO}_{2}\right)$, $\mathrm{KOH}(120 \mathrm{mM} \mathrm{ZnO}$ was diluted in $2.7 \mathrm{M} \mathrm{KOH}$ aqueous solution), and $9 \mathrm{mM} \mathrm{InCl}_{3}$ similarly to that described in [13] for $\mathrm{ZnO}$ :In thin films on glass substrates. Hot water $\left(90^{\circ} \mathrm{C}\right)$ was used as an anionic precursor. One SILAR growth cycle included the following three steps:

(1) immersion of the fabric into a cationic precursor for $2 \mathrm{~s}$;

(2) immersion of this fabric immediately into hot $\left(90{ }^{\circ} \mathrm{C}\right)$ water for $2 \mathrm{~s}$ to form a $\mathrm{ZnO}$ :In monolayer;

(3) rinsing of the substrate in a separate $\mathrm{H}_{2} \mathrm{O}$ beaker for $5 \mathrm{~s}$ to remove loosely bound particles.

By repeating such deposition cycles for 50-400 times, we obtained $\mathrm{ZnO}$ :In films on cotton and polyester fibers, i.e. $\mathrm{ZnO}: \mathrm{In} / \mathrm{Ct}$ and $\mathrm{ZnO}: \mathrm{In} / \mathrm{PET}$ samples, respectively. Then, we used post-growth vacuum annealing of $\mathrm{ZnO}: \mathrm{In} / \mathrm{Ct}$ and $\mathrm{ZnO}: \mathrm{In} / \mathrm{PET}$ samples at $200{ }^{\circ} \mathrm{C}$ for 1 or $2 \mathrm{~h}$. Due to the flame retardancy and thermal insulation properties of $\mathrm{ZnO}$ coatings [3], the $\mathrm{ZnO}: \mathrm{In} / \mathrm{Ct}$ and $\mathrm{ZnO}: \mathrm{In} / \mathrm{PET}$ samples withstand post-growth vacuum annealing at $200{ }^{\circ} \mathrm{C}$ for $2 \mathrm{~h}$.

\subsection{Materials Characterization}

Morphology of uncoated Ct and PET fabrics as well as $\mathrm{ZnO}: \mathrm{In} / \mathrm{Ct}$ and $\mathrm{ZnO}$ :In/PET samples was observed by scanning electron microscopy (SEM) in the secondary electron mode. The SEM instrument "Tescan Vega 3 LMH" (Czech Republic) operated at an accelerating voltage of $30 \mathrm{kV}$ without the use of additional conductive coatings, when scanning the conductive $\mathrm{ZnO}: \mathrm{In}$ coated textiles. However, for morphology studies by SEM of the pristine $\mathrm{Ct}$ and PET fabrics we used thin $\mathrm{Cr}$ film ( 10-15 nm thick) as a conductive coating, which was evaporated in vacuum at $10^{-4} \mathrm{~Pa}$ residual gas pressure immediately before SEM research. Chemical analysis of the samples was carried out by X-ray fluorescence (XRF) microanalysis using an energy dispersive spectrometry (EDS) system "Bruker XFlash 5010" (Germany). Energy dispersion spectra were taken from $100 \times 100 \mu \mathrm{m}$ sample areas. Quantification of the spectra was fulfilled in the self-calibrating detector mode.

Optical properties of the $\mathrm{ZnO}: \mathrm{In} / \mathrm{Ct}$ and $\mathrm{ZnO}: \mathrm{In} / \mathrm{PET}$ samples were studied in the wavelength $(\lambda)$ range 300 $1100 \mathrm{~nm}$ using an UV-Vis-NIR spectrophotometer "SF2000" (Russia) equipped with "SFO-2000" specular and diffuse reflection attachment. Optical reflection measurements were performed at a light incidence angle $\vartheta=8^{\circ}$ relative to the normal to the surface. Optical band gaps $E_{g}$ for direct allowed transitions in $\mathrm{ZnO}$ :In coatings were determined by using diffuse reflectance spectra $R(\lambda)$ from the Kubelka-Munk function [8]: 


$$
F(R)=\frac{(1-R)^{2}}{2 R} .
$$

According to [8], a plot of $(F(R) \cdot h v)^{2}$ vs $h v$ yields the direct band gap value $E_{g}$ of the film by extrapolating $(F(R) \cdot h v)^{2}$ linear part on $h v$.

To analyze the phase compositions and structural parameters of $\mathrm{ZnO}: \mathrm{In}$ coatings in $\mathrm{ZnO}: \mathrm{In} / \mathrm{Ct}$ and ZnO:In/PET samples we used an X-ray diffractometer "Shimadzu XRD-6100" (Japan). Scanning was performed with Bragg-Brentano focusing $(\theta-2 \theta)$. The experimental interplanar $d$-spacing was calculated according to the Bragg's law, which describes the condition on $\theta$, at which the constructive interference is maximum:

$$
n \lambda_{x}=2 d \sin \theta
$$

where $n$ is a positive integer, $\lambda_{x}$ is the wavelength of the incident X-ray (CuKa radiation, $\lambda_{x}=1.54060 \AA$ ).

The crystalline phases were identified by comparing the experimental diffraction patterns with the reference $\mathrm{ZnO}$ powder XRD data in the JCPDS database by using PCPDFWIN v.1.30 software. In accordance with $[13,15,16]$, it was supposed that coherent-scattering domains in $\mathrm{ZnO}$ :In coatings estimated by analyzing the broadening of X-ray diffraction peaks are equal to the average sizes $D$ of the nanocrystalline $\mathrm{ZnO}: \mathrm{In}$ grains calculated using the Scherrer's formula $[2,15,16]$ :

$$
D=(0.9 \cdot \lambda) /(\beta \cdot \cos \theta)
$$

where $\lambda$ is the X-ray wavelength; $\beta=B-b, B$ is the observed full width at half maximum (FWHM) and $b$ is the broadening of the peak due to the instrument in radians, $\theta$ denotes the Bragg's angle of the X-ray diffraction peak (002).

According to [13], microstrains $\varepsilon$ in $\mathrm{ZnO}$ :In nanocrystals were calculated as $\varepsilon=\Delta d / d$ (where $d$ is the crystal interplanar spacing according to JCPDS and $\Delta d$ is the difference between the corresponding experimental and reference interplanar spacings). Dislocation density of $\mathrm{ZnO}$ :In coatings on $\mathrm{Ct}$ and PET fibers in $\mathrm{ZnO}: \mathrm{In} / \mathrm{Ct}$ and $\mathrm{ZnO}: \mathrm{In} / \mathrm{PET}$ samples was evaluated through $1 / D^{2}$ as in [2]. The crystal lattice constants $a$ and $c$ were identified from the positions of the indexed lines (002) and (004) in the X-ray diffraction patterns by the Nelson-Reilly (N-R) graphical extrapolation method, and refined using the least-squares method by UnitCell (UC) software on the basis of all recorded reflections in the X-ray diffraction patterns in accordance with $[17,18]$. The texture quality was estimated by the Harris method $[2,13,19]$. The pole density $P_{i}$, which determines an axis of the crystal plane that is oriented normal to the surface, was calculated according to the equation $[2,13,19]$ :

$$
P_{i}=\left(I_{i} / I_{0 i}\right) /\left[1 / N \sum_{i=1}^{N}\left(I_{i} / I_{0 i}\right)\right]
$$

where $I_{i}$ and $I_{0 i}$ are the integral intensity of the $i$-th diffraction peak in the XRD pattern of the film and the etalon, respectively; $N$ is the number of lines presented in the diffraction. The texture axis has the index, which corresponds to the largest value of $P_{i}$. The orientation factor $f$ for the relevant direction was calculated from the formula [13]:

$$
f=\sqrt{1 / N \sum_{i=1}^{N}\left(P_{i}-1\right)^{2}}
$$

\subsection{Wettability Tests for $\mathrm{ZnO}: \mathrm{In} / \mathrm{Ct}$ and ZnO:In/PET Textiles}

The standard sessile drop method, the drop evaporation observations, the liquid dispensing and retracting method, and the tilt angle measurements well described in $[1,5,7,8,10-12,14]$ were used to analyze the surface hydrophilicity/hydrophobicity of $\mathrm{ZnO}: \mathrm{In} / \mathrm{Ct}$ and $\mathrm{ZnO}: \mathrm{In} / \mathrm{PET}$ textiles. The water drop image on the textile surface was recorded using a "Samsung PL55" digital camera (Korea), whose lens was placed at the level of the surface using a support. The test was repeated for five different positions on each fabric surface for the determination of the average $C A$ value. The $C A$ value on the horizontal surface of $\mathrm{Ct}, \mathrm{ZnO}: \mathrm{In} / \mathrm{Ct}$, PET, and $\mathrm{ZnO}: \mathrm{In} / \mathrm{PET}$ fabrics as well as the values of $\vartheta_{\text {Rec }}$ and $\vartheta_{A d v}$ on the horizontal or inclined PET and $\mathrm{ZnO}: \mathrm{In} / \mathrm{PET}$ textile surfaces were determined by analyzing the drop profile in images according to the technique presented in [10] by the formula:

$$
\tan (\vartheta / 2)=h / r
$$

where $h$ is the droplet height over the textile surface, $r$ is the droplet base radius on the surface.

In the sessile drop method, static $C A$ values were obtained as follows. A distilled water droplet with a volume ( $V$ ) of $\sim 1.8 \mu \mathrm{l}$ was placed using a syringe onto the horizontal surface of $\mathrm{Ct}, \mathrm{ZnO}: \mathrm{In} / \mathrm{Ct}$, PET or $\mathrm{ZnO}: \mathrm{In} / \mathrm{PET}$ textile sample. Here we determined $V$ values through conventional geometric formulas for calculating the sphere or its segment volumes depending on its shape.

According to [14], observations of the evaporation of drops "sitting" on the horizontal surfaces were used to determine the wetting mechanism for PET and $\mathrm{ZnO}: \mathrm{In} / \mathrm{PET}$ fabrics by the shape of the dependence of the $C A \vartheta$ on the drop volume $V$. To obtain the function $\vartheta(V)$, we observed water-drop evaporation on the surface of PET or ZnO:In/PET fabric. For this, 2-5 min series of photographs of the drop were taken with snapshots occurring every $60 \mathrm{~s}$. According to [11], two extreme cases can occur at a rough, hydrophobic surface when a water drop is applied. One possibility is that the drop could maintain contact with the entirety of the rough surface (the Wenzel state), thus increasing the interfacial contact area. Alternatively, a drop on a superhydrophobic surface could skip between the peaks of the roughness (the Cassie-Baxter state), thus leaving a patchwork of solid-liquid and liquid-vapor interfaces below it. When the function $\vartheta(V)$ is shaped as a horizontal straight line, the Cassie-Baxter state takes place, but if the dependence $\vartheta(V)$ steadily decreases with decreasing $V$, we have the Wenzel state [14]

Authors [12] indicate that superhydrophobic surfaces refer to surfaces with excellent water repellency with a water $C A$ exceeding $150^{\circ}$, and also with low $C A H$ less than $10^{\circ}$. In accordance with [12], $C A H$ is related to the force of adhesion to a surface, and the method for lowering the surface free energy is a basic control for superhydrophobic characteristics. Here we determined the wetting hysteresis $C A H$ as the difference between ad- 
vancing and receding $C A s, C A H=\vartheta_{A d v}-\vartheta_{R e c}$, by means of the liquid dispensing and retracting method, according to [11]. For the measurement of $\vartheta_{A d v}$ and $\vartheta_{R e c}$ on a flat sample, an initial water droplet of $2 \mu \mathrm{l}$ volume was dispensed onto the surface with a needle positioned inside the droplet. Then, $6 \mu \mathrm{l}$ of water was progressively added until the $C A$ reached a constant value, which was recorded as the advancing $C A \vartheta_{A d v}$. Then, $6 \mu$ of water was progressively removed until the $C A$ reached another constant value, noted as the receding $C A \vartheta_{R e c}$.

To determine the wetting hysteresis $C A H$ by using a tilting plate in accordance with $[11,14]$, the $\mathrm{ZnO}$ :In/PET fabric surface with a settled water drop was inclined. The tilt angle (TA) to the horizon was changed in the $6-32^{\circ}$ range in 3-11 degree increments. Then, the water drop was photographed and its receding (upper) and advancing (lower) $C A s, \vartheta_{\text {Rec }}$ and $\vartheta_{A d v}$, respectively, were measured. Their difference equaled to $C A H$ at the corresponding $T A$.

To clarify the possibility of fabric self-cleaning due to the mobility of water drops on its surface, the $S A$ (or roll-off angle) that is the angle to which the surface must be tilted for sliding or roll-off of water drops, was measured in accordance with [9] via a common tilting plate method as follows. The tested $\mathrm{ZnO}$ :In/PET fabric sample was fixed by double-sided adhesive tape on the table, whose $T A$ changed in the $6-32^{\circ}$ range in $3-11$ degree increments. Distilled water was dropped $(V \approx 2 \mu \mathrm{l})$ from a syringe adjusted at $1 \mathrm{~cm}$ above the $\mathrm{ZnO}:$ In/PET fabric surface.

Changes in the properties of textile surface wetting upon exposure to UV radiation were studied as described in [14] by exposing the textile surface to a $26 \mathrm{~W}$
UV lamp. The UV wavelengths were in the $315-400 \mathrm{~nm}$ range. UV irradiation of the $\mathrm{ZnO} \mathrm{In} / \mathrm{PET}$ textiles was performed for $60 \mathrm{~min}$. During the exposure of the sample to UV radiation, the drop profile was imaged using a digital camera. To observe restoration of the $C A$ values of the $\mathrm{ZnO}: \mathrm{In} / \mathrm{PET}$ surfaces after UV irradiation, the samples were stored in the dark for 9 days; the drop profiles were photographed in a few days. For each analysis, water drops were applied to five different points on the $\mathrm{ZnO}$ :In/PET textile surface to improve the measurement accuracy.

\section{RESULTS AND DISCUSSION}

As is seen from the photographs and SEM images in Fig. 1, the woven fabrics $\mathrm{Ct}$ and PET chosen by us differ not only in density (a), but also in the smoothness of the fibers (b). The natural Ct sample in Fig. 1 is woven from fibers of complex shape with a rough surface, while the synthetic PET fabric has smooth cylindrical fibers of $\sim 10 \mu \mathrm{m}$ in diameter.

Fig. 1 also contains the corresponding XRF spectra. Note that $\mathrm{Cr}$ in the XRF spectra belongs to the electrically conductive chromium film and is not a part of cotton or polyester fabrics. Chemical compositions of these fabrics obtained by EDS microanalysis are presented in Table 1. Table 1 does not indicate the impurities $\mathrm{Ca}, \mathrm{S}$ and $\mathrm{P}$ contained in PET in an amount of less than 1 at. \%. If we do not take into account impurities, the presence of which in PET is probably explained by the features of the manufacturing technology of this fabric, both fabrics are almost identical in the amount and ratio of $\mathrm{C}$ and $\mathrm{O}$ in the chemical composition. (a)
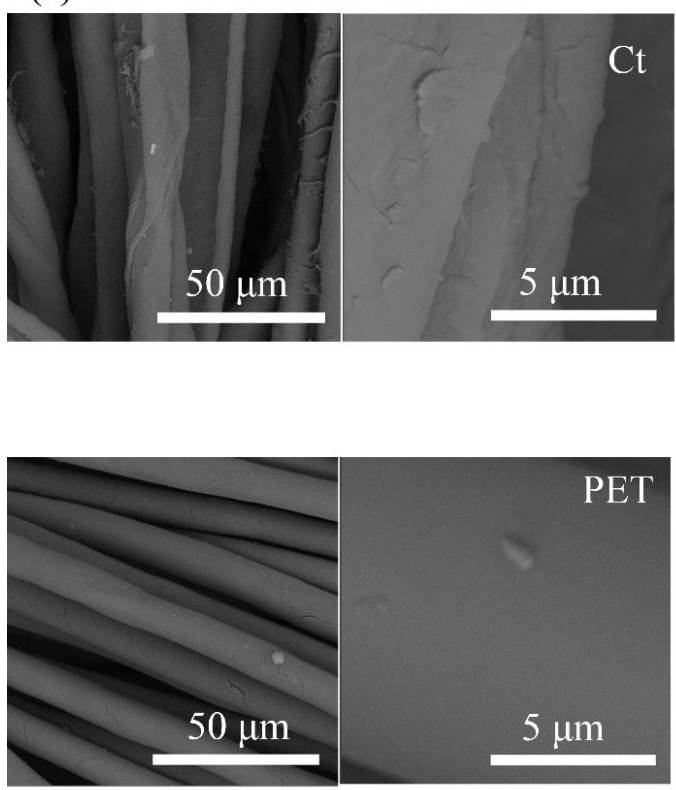
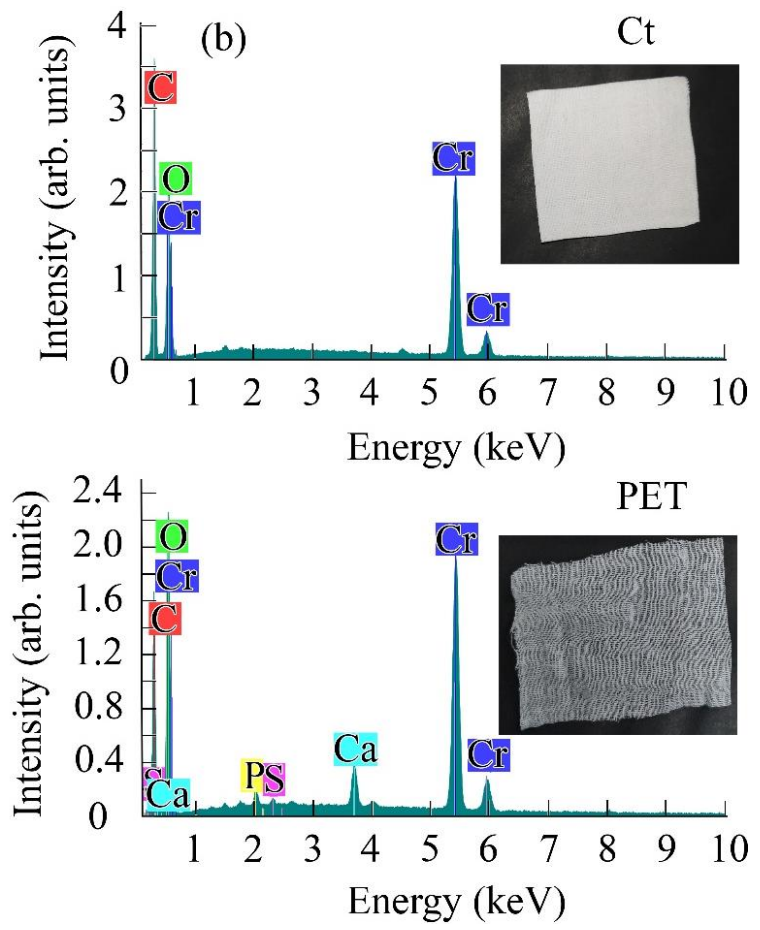

Fig. 1 - SEM images of the pristine cotton (Ct) and polyester (PET) fabrics (a) and the corresponding XRF data and photos (b) 
Table 1 - Chemical composition of $\mathrm{Ct}, \mathrm{ZnO}: \mathrm{In} / \mathrm{Ct}$, PET and $\mathrm{ZnO}: \mathrm{In} / \mathrm{PET}$ fabrics and the crystal structure of $\mathrm{ZnO}: \mathrm{In}$ in $\mathrm{ZnO}: \mathrm{In} / \mathrm{Ct}$ and $\mathrm{ZnO}: \mathrm{In} / \mathrm{PET}$ samples

\begin{tabular}{|c|c|c|c|c|c|c|c|c|c|c|c|}
\hline \multirow{4}{*}{ Textile sample } & \multicolumn{4}{|c|}{$\begin{array}{l}\text { Chemical composition } \\
\text { according to EDS, at. \% }\end{array}$} & \multicolumn{7}{|c|}{ Crystal structure of $\mathrm{ZnO}$ :In according to XRD } \\
\hline & \multirow[t]{3}{*}{$\mathrm{Zn}$} & \multirow[t]{3}{*}{$\mathrm{C}$} & \multirow[t]{3}{*}{ In } & \multirow[t]{3}{*}{$\mathrm{O}$} & \multirow{3}{*}{$D, \mathrm{~nm}$} & \multirow{3}{*}{$\begin{array}{c}\varepsilon \cdot 10^{3}, \\
\text { arb. unit }\end{array}$} & \multirow{3}{*}{$\begin{array}{c}1 / D^{2} \cdot 10^{-12} \\
\text { lines } \cdot \mathrm{m}^{-2}\end{array}$} & \multicolumn{4}{|c|}{$\begin{array}{c}\text { Lattice constants, } \AA \\
\text { (according to JCPDS \#36-1451, } \\
a=3.249 \AA, c=5.206 \AA \text { ) }\end{array}$} \\
\hline & & & & & & & & \multicolumn{2}{|c|}{ according to N-R } & \multicolumn{2}{|c|}{ according to UC } \\
\hline & & & & & & & & $a$ & $c$ & $a$ & $c$ \\
\hline $\mathrm{Ct}$ & - & 53 & - & 47 & - & - & - & - & - & - & - \\
\hline ZnO:In/Ct (200 cycles) & 7 & 23 & 3 & 36 & 50 & 2.7 & 4.2 & 3.250 & 5.199 & 3.250 & 5.206 \\
\hline \begin{tabular}{|c|} 
PET \\
\end{tabular} & - & 46 & - & 53 & - & - & - & - & - & - & - \\
\hline ZnO:In/PET (400 cycles) & 32 & 23 & 2 & 43 & 70 & 2.0 & 2.2 & 3.245 & 5.206 & 3.246 & 5.200 \\
\hline
\end{tabular}

(a)

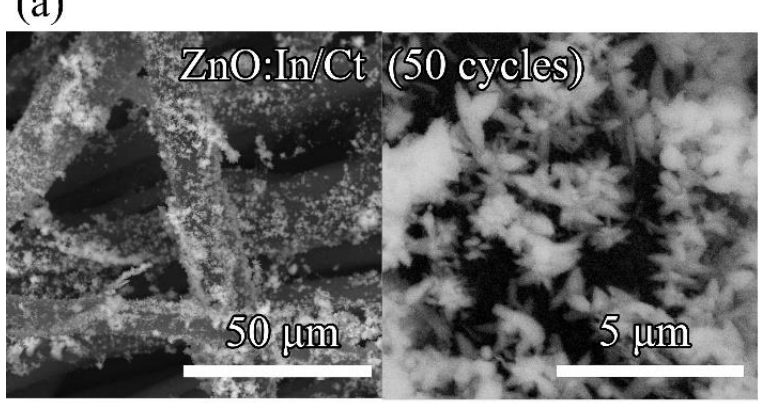

(b)

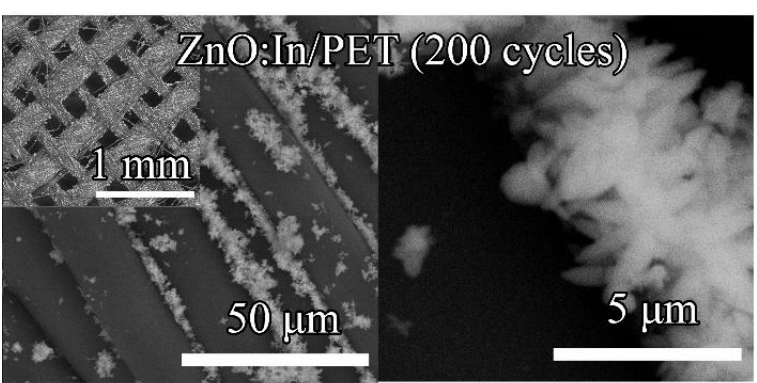

(c)

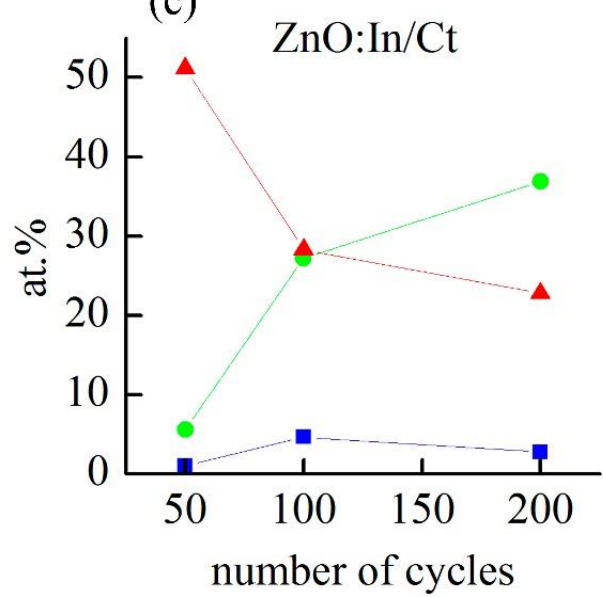

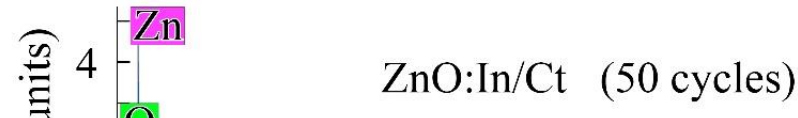

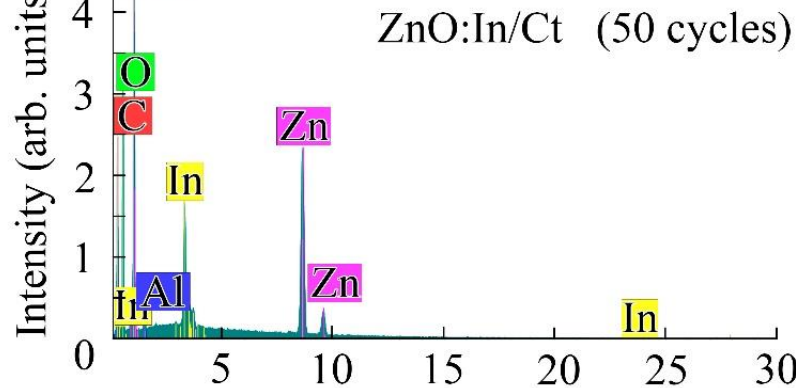

Energy (keV)

$\mathrm{ZnO}:$ In/PET (200 cycles)

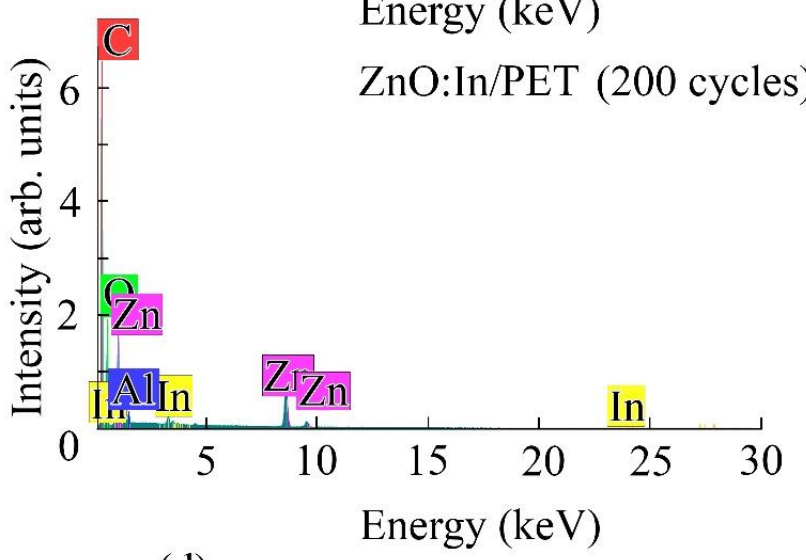

(d)

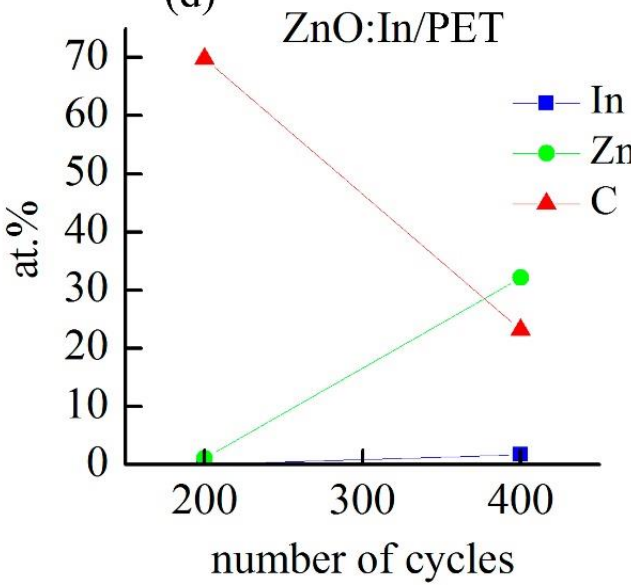

Fig. 2 - SEM images and XRF data of $\mathrm{ZnO}: \mathrm{In} / \mathrm{Ct}$ textile with $\mathrm{ZnO}: \mathrm{In}$ coating obtained by 50 SILAR cycles (a) and ZnO:In/PET textile with ZnO:In coating obtained by 200 SILAR cycles (b). Dependence of the chemical composition on the number of SILAR cycles for $\mathrm{ZnO}: \mathrm{In} / \mathrm{Ct}$ textile (c) and $\mathrm{ZnO}: \mathrm{In} / \mathrm{PET}$ textile (d) 
Fig. 2 shows the influence of the material and structure of the fibers on the intensity of the build-up of an indium-doped $\mathrm{ZnO}$ layer by SILAR method. As seen from SEM images in Fig. 2a, it is enough to carry out 50 SILAR cycles for completely uniform coating of the cotton surface with ZnO:In nanorods. The XRF spectrum of the textile $\mathrm{ZnO}: \mathrm{In} / \mathrm{Ct}$ (50 cycles) shows fairly intense peaks related to zinc and indium atoms. First of all, it is explained by the cellulose molecules, from which cotton fibers are formed. These molecules contain many polar hydroxyl groups allowing them to interact with polar and ionic components of the solutions to obtain $\mathrm{ZnO}$ seed layers, and then to deposit $\mathrm{ZnO}: \mathrm{In}$ nanorods. In addition, a rough surface of cotton fibers provides a large number of crystallization centers on which $\mathrm{ZnO}$ seed layers and $\mathrm{ZnO}$ :In nanorods are formed. A different picture is observed for smooth polyester fibers in Fig. 2b, including because PET molecules do not contain hydroxyl groups and therefore are worse wetted by aqueous solutions and interact less with the components of these solutions. The surface of the PET fabric looks like uniformly coated with $\mathrm{ZnO}$ in the SEM image of ZnO:In/PET sample (200 cycles) obtained with a small magnification in Fig. 2b. However, it is seen in the images recorded with larger magnifications in Fig. 2b that $\mathrm{ZnO}$ :In nanorods are very unevenly distributed on the surface of the PET fibers, they are only in the separate sections.

In support of this, the XRF spectrum of $\mathrm{ZnO}$ :In/PET
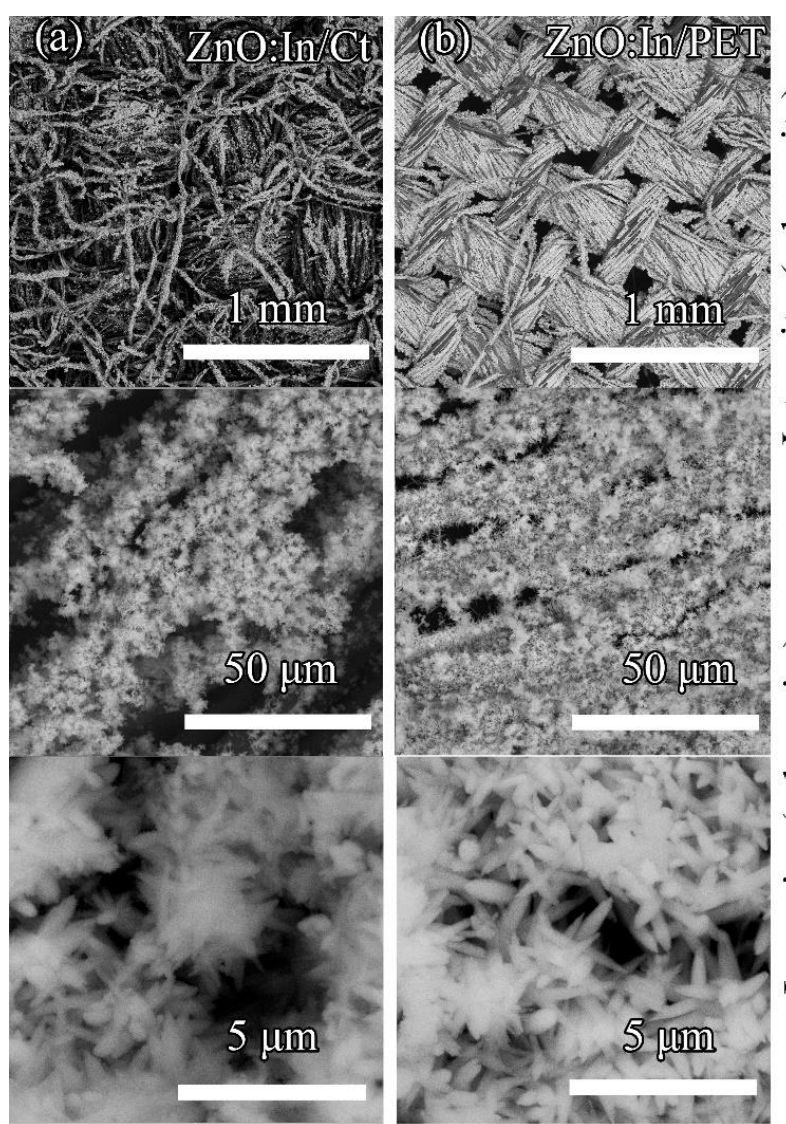

fabric sample (200 cycles) in Fig. 2b contains very few zinc and indium atoms. Note, that $\mathrm{Al}$ in the all XRF spectra is not a part of fabrics, it is generated by aluminium table and holder for the samples of the vacuum chamber, in which the X-ray fluorescence microanalysis was carried out.

The graphs in Fig. 2c, $d$ are plotted using EDS data. They show that the surfaces of both fabrics become increasingly covered with $\mathrm{ZnO}$ :In as the number of SILAR cycles increases, which is evidenced by the growth in the atomic percentage of $\mathrm{Zn}$ and $\mathrm{In}$ and the decline in the percentage of $\mathrm{C}$ as one of the main components of $\mathrm{Ct}$ and PET fabrics. A comparison of the plots in Fig. 2c and Fig. $2 \mathrm{~d}$ also shows that the layer of $\mathrm{ZnO}$ :In nanorods on cotton made using 200 SILAR cycles is about the same thickness as the $\mathrm{ZnO}$ :In nanorod layer obtained for 400 SILAR cycles on polyester. Therefore, we will further research these samples, namely $\mathrm{ZnO}: \mathrm{In} / \mathrm{Ct}$ (200 cycles) and ZnO:In/PET (400 cycles).

As seen from Fig. 3, sharp $\mathrm{ZnO}$ :In nanorods with a length of about $1.5 \mu \mathrm{m}$ and $300-400 \mathrm{~nm}$ in diameter very similar to each other grew on the entire surface of fibers of the Ct and PET fabrics with an average cross-section of 10-20 $\mu \mathrm{m}$. Thus, together they formed coral-like hierarchical structures $\mathrm{ZnO}: \mathrm{In} / \mathrm{Ct}$ and $\mathrm{ZnO}: \mathrm{In} / \mathrm{PET}$, respectively, which look like superhydrophobic surfaces presented in [20]. XRF spectra of ZnO:In/Ct (200 cycles) and $\mathrm{ZnO}: \mathrm{In} / \mathrm{PET}$ (400 cycles) fabrics are presented in Fig. 3. Table 1 contains the corresponding EDS data.

(c)
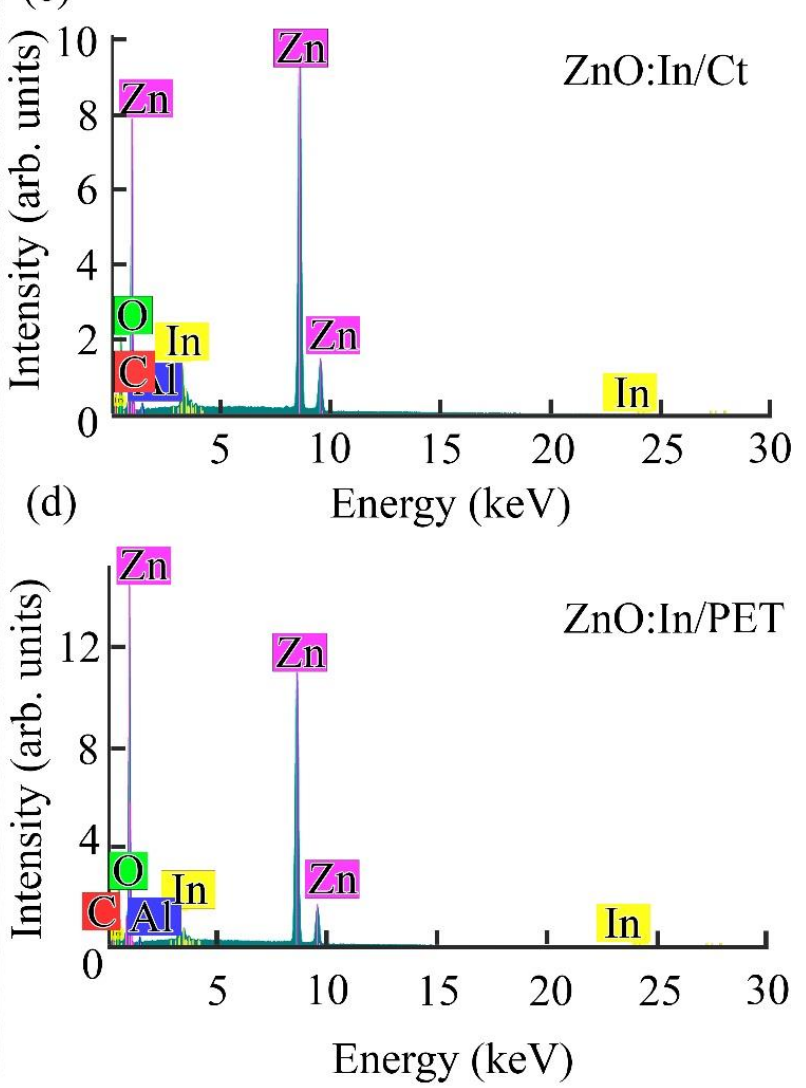

Fig. 3 - SEM images and XRF data of ZnO:In/Ct textile with ZnO:In layers obtained via 200 SILAR cycles (a and c, respectively) and $\mathrm{ZnO}: \mathrm{In} / \mathrm{PET}$ textile with $\mathrm{ZnO}$ :In layers obtained via 400 SILAR cycles (b and d, respectively) 


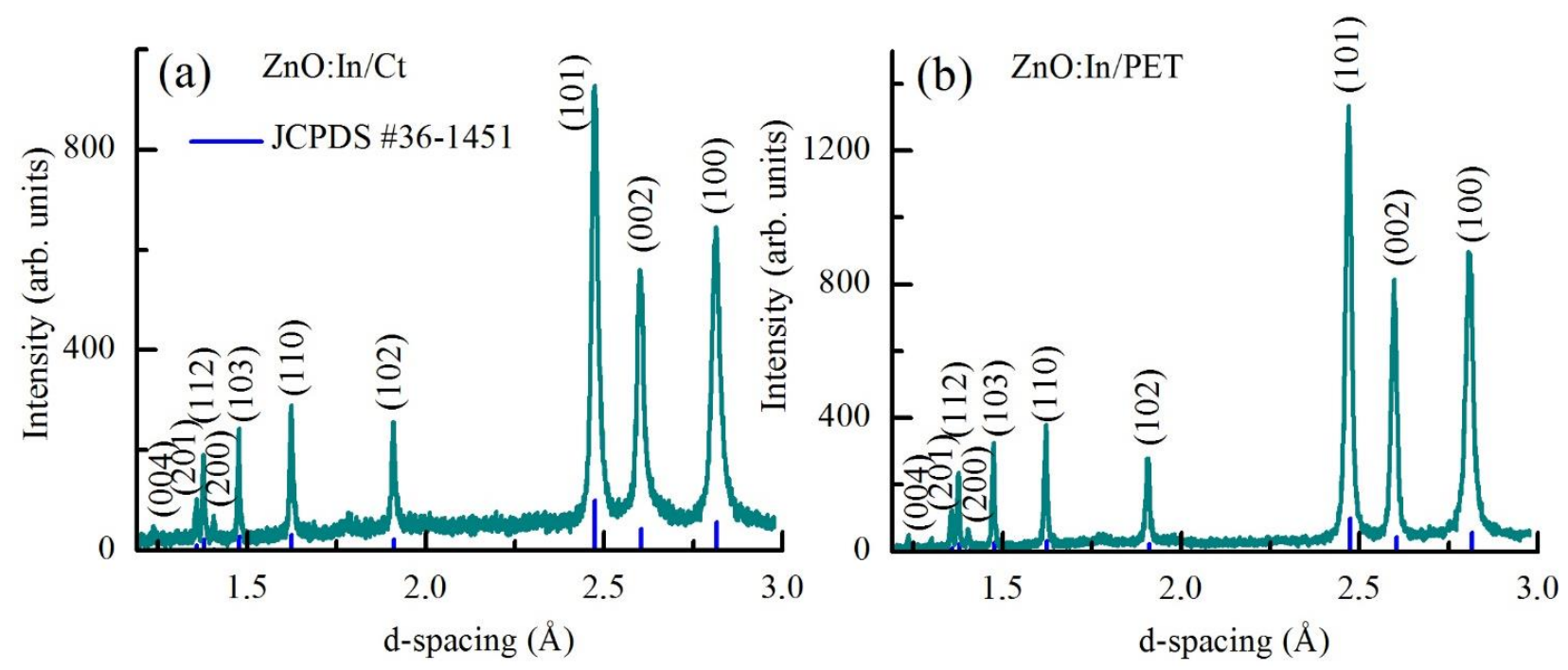

Fig. 4 - XRD patterns of ZnO:In/Ct (200 cycles) (a) and ZnO:In/PET (400 cycles) (b) fabrics. The dashes on the scale indicate the $d$-spacing of $\mathrm{ZnO}$ according to the reference X-ray powder diffraction JCPDS \#36-1451

Fig. 4 shows experimental XRD patterns for these fabrics. Each has ten X-ray diffraction maxima. According to JCPDS \#36-1451, all these peaks belong to the hexagonal wurtzite $\mathrm{ZnO}$ structure. Since no extraneous peaks were detected in the XRD patterns of indiumdoped $\mathrm{ZnO}$ films, it is possible to argue the formation of single-phase polycrystalline ZnO:In solid solutions. Calculations of crystallite sizes by the Scherrer's formula (3) using a broadening of X-ray diffraction peaks showed $D \approx 50 \mathrm{~nm}$ in ZnO:In/Ct (200 cycles) and $D \approx 70 \mathrm{~nm}$ in $\mathrm{ZnO}: \mathrm{In} / \mathrm{PET}$ (400 cycles). The latter confirms the nanocrystalline structure of $\mathrm{ZnO}$ :In nanorods on the surface of both fabrics. Analysis of the XRD data given in Table 1 presents weak microstrains $\varepsilon$ and small dislocation densities in the $\mathrm{ZnO}$ :In crystal lattice caused by the presence of point defects, in particular, indium in the interstitial and substitutional sites, i.e. $\mathrm{In}_{\mathrm{i}}$ and $\mathrm{InZn}$, respectively. The crystal lattice constants of these $\mathrm{ZnO}$ :In nanorods are approximately the same as the reference $\mathrm{ZnO}$ according to JCPDS \#36-1451 (Table 1). As seen from the SEM images in Fig. 3, $\mathrm{ZnO}: \mathrm{In}$ nanorods are oriented perpendicular to the entire surface of the fibers, which especially in PET have a cylindrical shape. Therefore, our calculations by equations (4) and (5) naturally showed the absence of axial texture in any direction $\left(P_{i} \approx 1, f \approx 0.1\right)$.

The diffuse reflectance spectra in Fig. 5a confirm the significant optical diffuse reflectance in the entire visible range for all investigated fabrics: $\mathrm{Ct}, \mathrm{ZnO}: \mathrm{In} / \mathrm{Ct}$, $\mathrm{PET}$, and $\mathrm{ZnO}: \mathrm{In} / \mathrm{PET}$. The band gap $E_{g}$ for direct optical transitions in $\mathrm{ZnO}$ :In obtained from the KubelkaMunk function (Fig. 5b) equals $3.18 \mathrm{eV}$ for $\mathrm{ZnO}: \mathrm{In} / \mathrm{Ct}$ (200 cycles) and $3.15 \mathrm{eV}$ for $\mathrm{ZnO}: \mathrm{In} / \mathrm{PET}$ (400 cycles), which is close to $E_{g}=3.37 \mathrm{eV}$ for bulk $\mathrm{ZnO}$ [2].

Wettability studies have shown that the type of fiber has a significant effect on the hydrophilicity/hydrophobicity of the textile. Thus, because of many hydroxyl groups in cellulose molecules, from which cotton fibers are formed, the samples of pristine $\mathrm{Ct}$ and $\mathrm{ZnO}: \mathrm{In} / \mathrm{Ct}$ textiles have low static $C A$ values both before and after vacuum annealing, $C A \approx 0-56^{\circ}$, that is, their surface is hydrophilic. As it is seen from Fig. $6 a$ and the graph in
Fig. 6, as-prepared ZnO:In/PET (400 cycles) sample is hydrophobic.
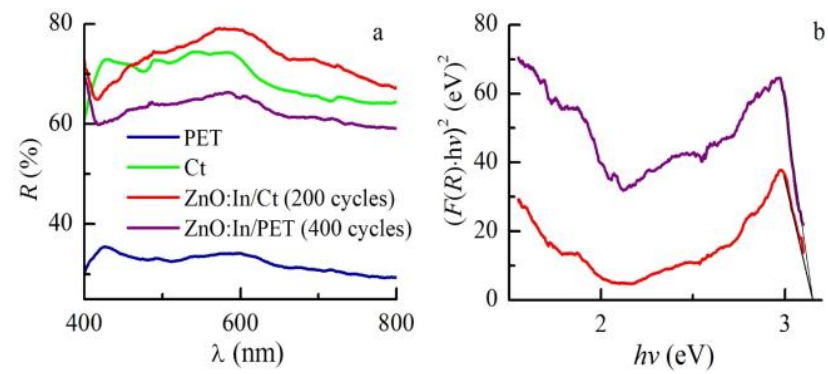

Fig. 5 - Optical properties of $\mathrm{Ct}$, $\mathrm{ZnO}: \mathrm{In} / \mathrm{Ct}$, PET, ZnO:In/PET textiles: (a) diffuse reflectance spectra; (b) graphs for finding $E_{g}$ by means of the Kubelka-Munk function $F(R)$ for $\mathrm{ZnO} \mathrm{In} / \mathrm{Ct}$ (200 cycles) and $\mathrm{ZnO}: \mathrm{In} / \mathrm{PET}$ (400 cycles)

From the observations of the evaporation of the "sitting" water drops, it can be seen that as the size of a drop on its surface decreases from 1.8 to $0.6 \mu \mathrm{l}$, the $C A$ decreases from $140^{\circ}$ to $90^{\circ}$, which is characteristic of the Wenzel state, when water contacts the entire surface of the base [3]. As seen in Fig. 6b, c, if ZnO:In/PET (400 cycles) fabrics were subjected to the post-growth vacuum annealing at $200{ }^{\circ} \mathrm{C}$ for 1 or $2 \mathrm{~h}$, the $C A$ values, which correspond to superhydrophobicity $\left(C A \approx 160^{\circ}\right)[2,21]$, were ensured. The functions $C A(V)$ for the vacuum annealed $\mathrm{ZnO}: \mathrm{In} / \mathrm{PET}$ (400 cycles) fabrics in the graph in Fig. 6 are straight horizontal lines, which is characteristic of the Cassie-Baxter state [3, 17]. According to [22, 23 ], the surface hydroxylation through water adsorption and dissociation in the as-deposited via SILAR ZnO:In layers is the cause of insufficient hydrophobicity. Vacuum annealing ensures the desorption of water, hence the de-hydroxylation of the $\mathrm{ZnO}$ surface in $\mathrm{ZnO}$ :In/PET fabric. For comparison, in Fig. 6 (d and graph) it is shown that pristine PET fabric is hydrophobic (initial $C A=110^{\circ}$ ), its wettability obeys the Wenzel state.

Fig. 7 and Fig. 8 demonstrate rather small wetting hysteresis $C A H=10^{\circ}$ for water drops settled on $\mathrm{ZnO}: \mathrm{In} /$ PET (400 cycles) fabrics, which were subjected to the post-growth vacuum annealing at $200{ }^{\circ} \mathrm{C}$ for 1 and $2 \mathrm{~h}$, 

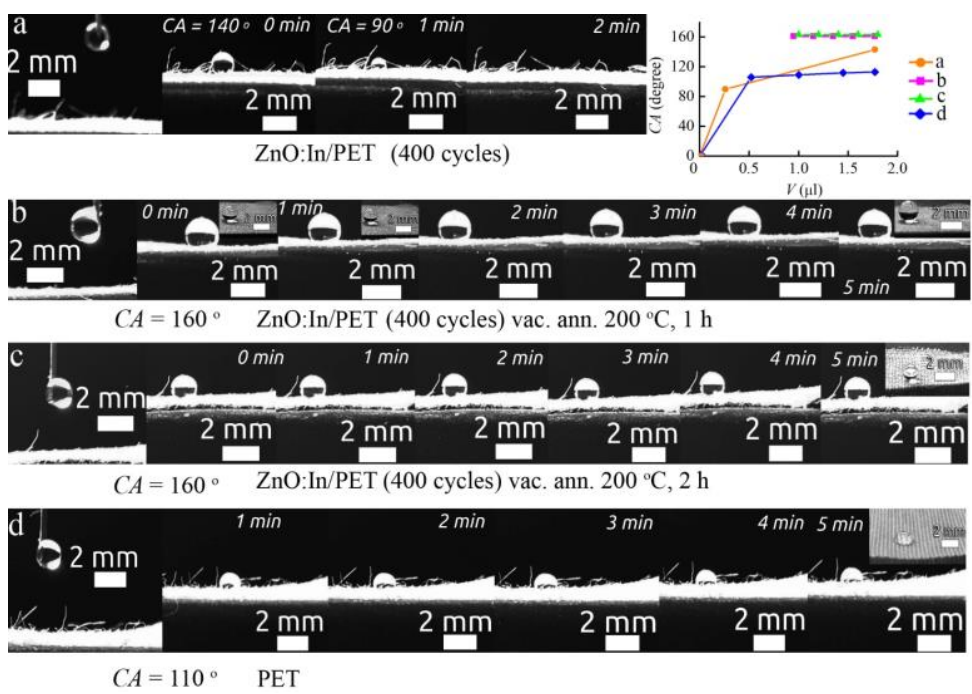

Fig. 6 - Photos of water drops on the horizontal surface of ZnO:In/PET (400 cycles) fabrics before (a) and after vacuum annealing at $200{ }^{\circ} \mathrm{C}$ for $1 \mathrm{~h}(\mathrm{~b})$ and $2 \mathrm{~h}$ (c) and the corresponding dependence of the contact angle $C A$ on the volume $V$ of a drop during its evaporation. (d) The same data for the pristine PET fabric

respectively. So, these surfaces have a relatively low surface free energy without any additional impregnation layer, as ZnO:In nanostructured films themselves provide superhydrophobicity.

Fig. 9 shows the process of determining the hysteresis of wetting for vacuum annealed $\mathrm{ZnO}$ :In/PET (400 cycles) fabrics by using a tilting plate in accordance with $[11,14]$. The differences between receding (upper) and advancing (lower) $C A s, \vartheta_{\text {Rec }}$ and $\vartheta_{A d v}$, respectively, equaled to $C A H$ at the corresponding $T A$. As can be seen from the graphs in Fig. 9, the TAs reflect, but are not equal to the $C A H s$, which is typical for superhydrophobic textiles [11] due to the typically rough surface of the fabric and because of the visible in Fig. 9 deflected fibers, which prevent the drop from sliding down.

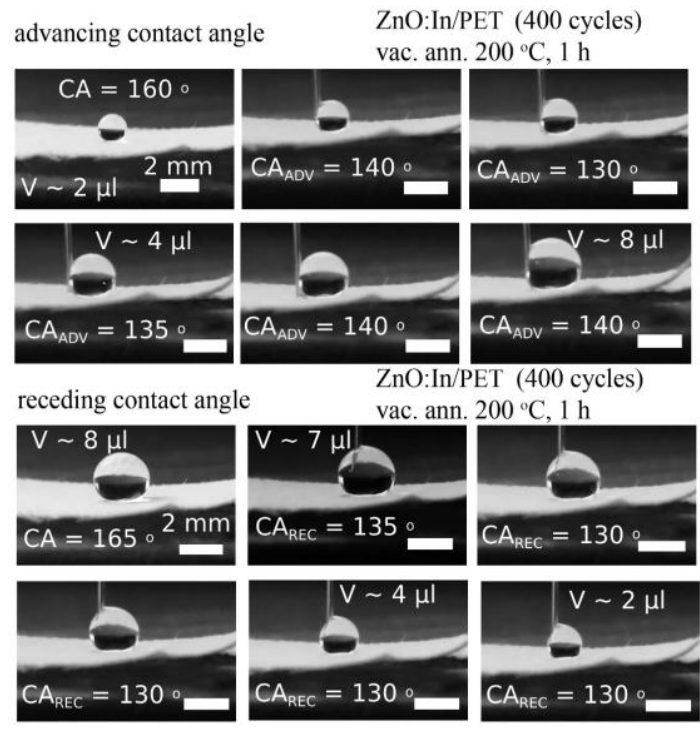

Fig. 7 - Photos of water drops settled on the horizontal surface of $\mathrm{ZnO}: \mathrm{In} / \mathrm{PET}$ (400 cycles) fabric subjected to the postgrowth vacuum annealing at $200{ }^{\circ} \mathrm{C}$ for $1 \mathrm{~h}$, which were used to determine the wetting hysteresis $C A H$ as the difference between advancing and receding $C A s, C A H=\vartheta_{A d v}-\vartheta_{R e c}=$ $140^{\circ}-130^{\circ}$ via the liquid dispensing and retracting method
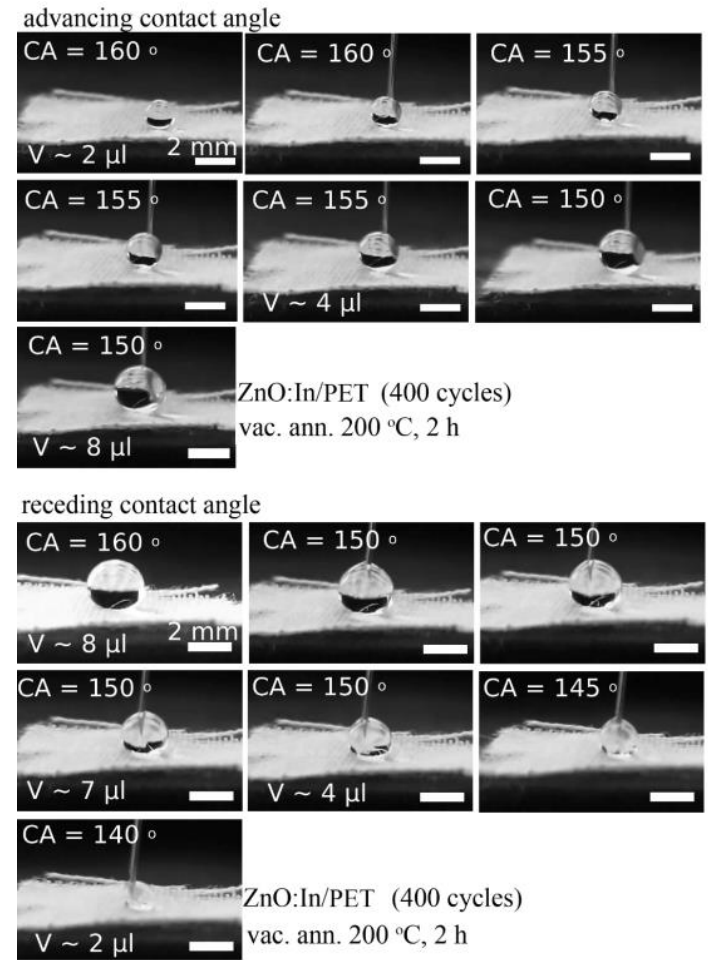

Fig. 8 - Photos of water drops settled on the horizontal surface of $\mathrm{ZnO}: \mathrm{In} / \mathrm{PET}$ (400 cycles) fabric subjected to the postgrowth vacuum annealing at $20{ }^{\circ} \mathrm{C}$ for $2 \mathrm{~h}$, which were used to determine the wetting hysteresis $C A H$ as the difference between advancing and receding $C A s, C A H=\vartheta_{A d v}-\vartheta_{\text {Rec }}=$ $150^{\circ}-140^{\circ}$ via the liquid dispensing and retracting method

To clarify the possibility of $\mathrm{ZnO}$ :In/PET fabric to be self-cleaned due to the mobility of water drops on its surface via the tilting plate method [9], we conducted a study, the results of which are presented in Fig. 10. Fig. 10 shows that in the case of $\mathrm{ZnO}$ :In/PET (400 cycles) fabric annealed for $1 \mathrm{~h}$ the $S A$ to roll-off of water drop is rather large, $\Delta \vartheta=43^{\circ}$. It is also seen in Fig. 10 that the water drop does not roll-off or slide off the $\mathrm{ZnO}$ :In/PET (400 cycles) textile surface annealed for $2 \mathrm{~h}$ 
at all, it may even hang below the surface. Since, according to the low $C A H$ values, these fabrics coated with nanostructured indium-doped $\mathrm{ZnO}$ layers have small adhesion to water, the visible cause of the observed phenomenon of the lack of the "lotus effect" is knockedout PET fibers, which keep the drop from moving.

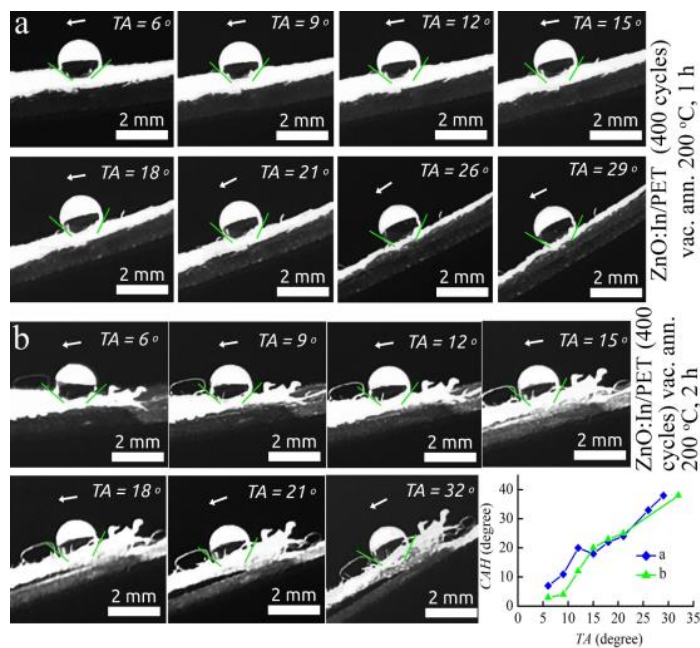

Fig. 9 - Photos of water drops settled on the tilted surface of ZnO:In/PET (400 cycles) fabrics subjected to the post-growth vacuum annealing at $200^{\circ} \mathrm{C}$ for 1 and $2 \mathrm{~h}$, and the corresponding dependences of $C A H=\vartheta_{A d v}-\vartheta_{R e c}$ vs. $T A$
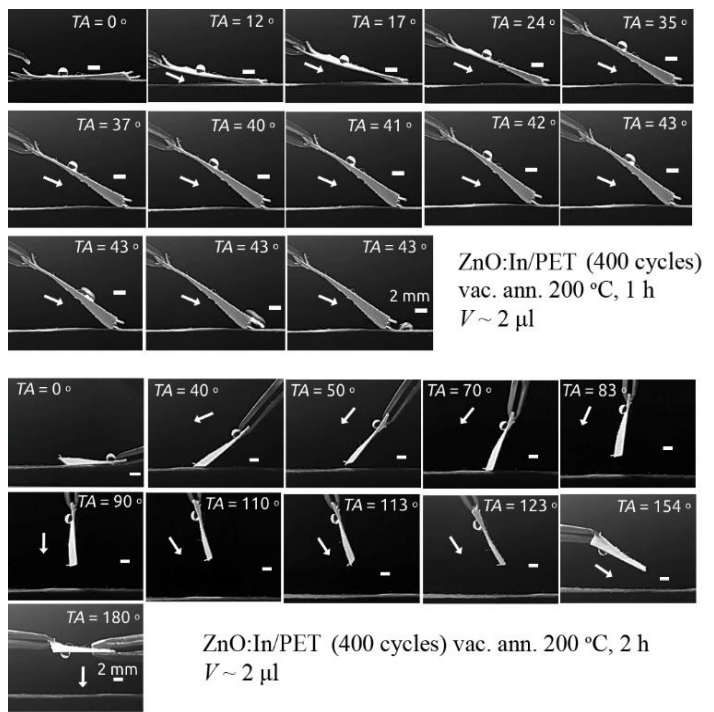

Fig. 10 - Photos of $2 \mu \mathrm{l}$ water drops settled on the tilted at TA surface of $\mathrm{ZnO}: \mathrm{In} / \mathrm{PET}$ (400 cycles) fabrics subjected to the post-growth vacuum annealing at $200{ }^{\circ} \mathrm{C}$ for 1 and $2 \mathrm{~h}$ in the experiments to determine the sliding or roll-off angles

It is important for the superhydrophobic coating to preserve its properties under the influence of solar light, which contains UV radiation. In other words, this coating must maintain $C A$ value as large as possible under the influence of UV illumination. However, it is known [1, 14, 24, 25] that the surface wettability of $\mathrm{ZnO}$ films usually changes from hydrophobicity to hydrophilicity via UV light irradiation. In [24], $C A$ of $\mathrm{ZnO}$ films prepared by a sol-gel process decreases from $97^{\circ}$ to $60^{\circ}$ for $14 \mathrm{~min}$ of UV exposure. According to $[24,25]$, UV-induced hydroxylation of $\mathrm{ZnO}$ surface is explained by the generation of electron-hole pairs in the $\mathrm{ZnO}$ lattice. The electrons and holes generated by $\mathrm{ZnO}$ under band-gap illumination move to the nanostructured $\mathrm{ZnO}$ surface, and electrons react with the lattice metal ions $\mathrm{Zn}^{2+}$ to form $\mathrm{Zn}^{+}$defective sites, which are favorable for hydroxyl adsorption. As indicated in [3], under UV influence in the presence of water and oxygen, at least two photochemical reactions occur simultaneously at the $\mathrm{ZnO}$ surface. The first is oxidation, in which photo-induced positive holes are involved, and the second is reduction, in which photoinduced negative electrons are involved. In these reactions, $\mathrm{OH}^{-}$and $\mathrm{O}_{2}{ }^{-}$are formed.

As a result, the water $C A$ of $\mathrm{ZnO}$ films, which were obtained in [25] via a hydrothermal method on a bamboo surface and chemically treated with octadecyltrichlorosilane, was changed from $153^{\circ}$ to approximately $0^{\circ}$. When, in [25], a $\mathrm{ZnO}$ nanostructured film was placed in the dark, oxygen atoms originating from the recovery of its initial state could gradually replace the oxygen vacancies, that is the wettability reconverted from superhydrophilicity to superhydrophobicity.

Authors [1], to maintain superhydrophobicity of the hydrothermally grown $\mathrm{ZnO}$ nanorods, coated them by $\mathrm{SiO}_{2}$ shells, and then the obtained core-shell $\mathrm{ZnO} @ \mathrm{SiO}_{2}$ nanorods were treated with octadecyltrimethoxysilane. In our work, we do not use any coatings for the modifying $\mathrm{ZnO}: \mathrm{In}$. As described above, the de-hydroxylation of the $\mathrm{ZnO}$ :In/PET fabric surface is ensured only by postgrowth vacuum annealing. Fig. 11 and Fig. 12 show that it is vacuum annealing at $200{ }^{\circ} \mathrm{C}$ for 1 and $2 \mathrm{~h}$, respectively, that keeps the shape of water droplets on the surface of $\mathrm{ZnO}: \mathrm{In} / \mathrm{PET}$ (400 cycles) fabric almost unchanged upon exposure to UV radiation. Fig. 11 also shows that water is absorbed into unannealed $\mathrm{ZnO}: \mathrm{In} / \mathrm{PET}$ (400 cycles) fabric after $10 \mathrm{~min}$ of UV light illumination. Note, that the hydrophobicity of this fabric is restored after UV irradiation, when unannealed $\mathrm{ZnO}$ :In/PET (400 cycles) sample was stored in the dark for 9 days (Fig. 11).

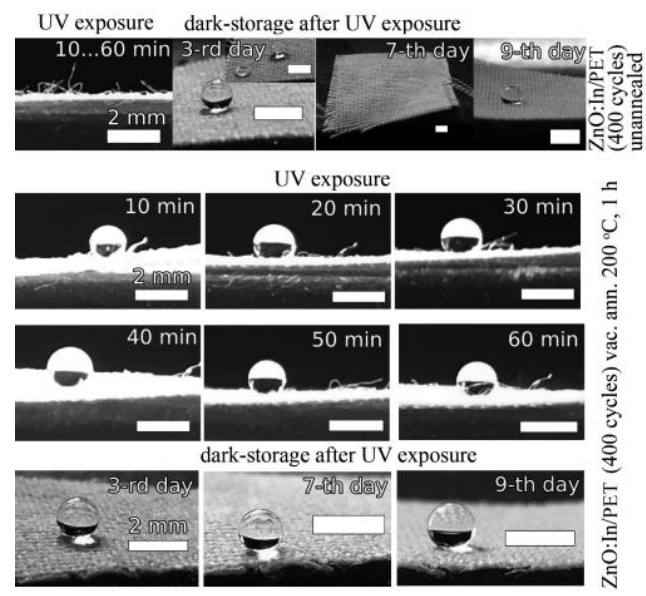

Fig. 11 - Photos of water drops settled on the surface of ZnO:In/PET (400 cycles) fabrics both unannealed and subjected to the post-growth vacuum annealing at $200{ }^{\circ} \mathrm{C}$ for $1 \mathrm{~h}$ in the experiments to determine changes in the CAs upon exposure to UV radiation ( $26 \mathrm{~W}$, wavelengths in the $315-400 \mathrm{~nm}$ range) for $60 \mathrm{~min}$ and to observe restoration of the superhy. drophobicity in the dark for 9 days 
The results of the $C A$ measuring shown in Fig. 13 confirm that vacuum-annealed $\mathrm{ZnO}: \mathrm{In} / \mathrm{PET}$ (400 cycles) fabrics under UV exposure are transformed from superhydrophobic to hydrophobic ( $C A$ reduced from $160^{\circ}$ to $\sim 130^{\circ}$ ), and that their superhydrophobic properties are returned after 9 days of storage in the dark.

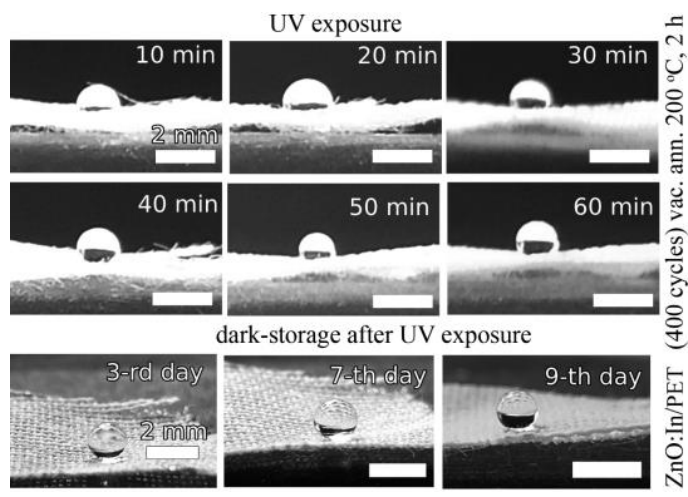

Fig. 12 - Photos of water drops settled on the surface of ZnO:In/PET (400 cycles) fabrics subjected to the post-growth vacuum annealing at $200{ }^{\circ} \mathrm{C}$ for $2 \mathrm{~h}$ in the experiments to determine changes in the CAs upon exposure to UV radiation ( $26 \mathrm{~W}$, wavelengths in the $315-400 \mathrm{~nm}$ range) for $60 \mathrm{~min}$ and to observe restoration of the superhydrophobicity in the dark for 9 days
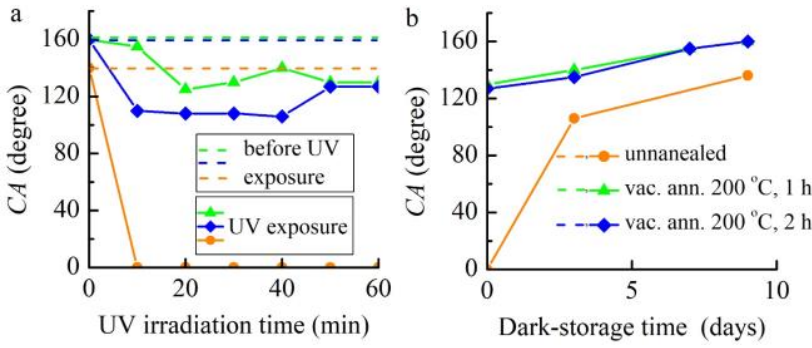

Fig. 13 - (a) Changes in the CAs upon exposure to UV radiation $(26 \mathrm{~W}$, wavelengths in the $315-400 \mathrm{~nm}$ range) during 0 $60 \mathrm{~min}$ for as-prepared $\mathrm{ZnO}: \mathrm{In} / \mathrm{PET}$ (400 cycles) fabrics and for the same fabrics subjected to the post-growth vacuum annealing at $200{ }^{\circ} \mathrm{C}$ for 1 and $2 \mathrm{~h}$. (b) Restoration of the CAs in the dark for as-prepared $\mathrm{ZnO}: \mathrm{In} / \mathrm{PET}$ (400 cycles) fabrics and the same fabrics subjected to the post-growth vacuum annealing at $200{ }^{\circ} \mathrm{C}$ for 1 and $2 \mathrm{~h}$

We also evaluated the rubbing and washing fastness of $\mathrm{ZnO}: \mathrm{In} / \mathrm{Ct}$ and $\mathrm{ZnO}: \mathrm{In} / \mathrm{PET}$ samples by means of their ultrasonic treatment during $0.5 \mathrm{~h}$ in distilled water at $30^{\circ} \mathrm{C}$ by using an ultrasonic cleaner "Jeken PS-20" (China) with ultrasonic power $120 \mathrm{~W}$ and frequency $40 \mathrm{kHz}$. The results showed no signs of removing $\mathrm{ZnO}$ :In film from the Ct surface. The explanation may be that in SILAR method, the growth of $\mathrm{ZnO}$ :In films occurs ion by ion both on the surface and inside the cotton fibers, which contributes to strong adhesion of the coating to the substrate in $\mathrm{ZnO}: \mathrm{In} / \mathrm{Ct}$ samples.
Similarly, ZnO:In/PET samples withstand to post-growth vacuum annealing at $200^{\circ} \mathrm{C}$ for $2 \mathrm{~h}$ and demonstrate rubbing and washing fastness, as they additionally demonstrate retention of superhydrophobicity after ultrasonic cleaning. High adhesion of $\mathrm{ZnO}$ :In coating to PET fibers is explained by the peculiarity of the ion by ion deposition by SILAR method over the entire PET surface where aqueous solutions can penetrate. This confirms the suitability of $\mathrm{ZnO}: \mathrm{In} / \mathrm{Ct}$ and $\mathrm{ZnO}: \mathrm{In} / \mathrm{PET}$ fabrics for use as wearable textiles.

\section{CONCLUSIONS}

In summary, it was shown in this work, that due to the inherent hydrophilicity of cotton, the rate of growth of nanostructured $\mathrm{ZnO}$ :In films on its surface by the hydrochemical SILAR method is much higher than that on the surface of hydrophobic synthetic polyester fibers (for PET fabric $C A=110^{\circ}$ ). For the same reason, the surface of $\mathrm{ZnO}: \mathrm{In} / \mathrm{Ct}$ fabric is hydrophilic as uncoated cotton. Via SILAR method we obtained arrays of very similar to each other nanocrystalline single-phase $\mathrm{ZnO}$ :In nanorods of $1.5 \mu \mathrm{m}$ in length and $300-400 \mathrm{~nm}$ in diameter with weak microstrains and small dislocation densities, which grew up on the entire surface of fibers of $\mathrm{Ct}$ and PET fabrics with an average cross-section of 10-20 $\mu \mathrm{m}$. Thus, together they formed coral-like hierarchical structures ZnO:In/Ct (200 cycles) and ZnO:In/PET (400 cycles), respectively. The optical band gaps of $\mathrm{ZnO}$ :In films in both materials are in the 3.153.18 range. As-prepared $\mathrm{ZnO}: \mathrm{In} / \mathrm{PET}$ (400 cycles) fabric is hydrophobic $\left(C A \approx 140^{\circ}\right)$. It became superhydrophobic $\left(C A \approx 160^{\circ}\right.$, wetting hysteresis $C A H=10^{\circ}$, CassieBaxter wetting state) and had a relatively low surface free energy without any additional impregnation layer, when was subjected to the post-growth vacuum annealing at $200^{\circ} \mathrm{C}$ for 1 or $2 \mathrm{~h}$. Upon exposure to UV radiation (26 W, wavelengths in the $315-400 \mathrm{~nm}$ range) for 60 min, vacuum annealed $\mathrm{ZnO}$ :In/PET (400 cycles) fabrics are transformed from superhydrophobic to hydrophobic, their $C A s$ reduced from $160^{\circ}$ to $\sim 130^{\circ}$ and returned after 9 days of storage in the dark. Thus, we presented here a simple and cheap method for creating superhydrophobic fabric that remains non-wettable under operating conditions in sunlight. The rubbing and washing fastness of $\mathrm{ZnO}: \mathrm{In} / \mathrm{Ct}$ textile and waterrepellent $\mathrm{ZnO}$ :In/PET fabric was confirmed by their ultrasonic treatment in distilled water at an ultrasonic power of $120 \mathrm{~W}$ and a frequency of $40 \mathrm{kHz}$.

\section{ACKNOWLEDGEMENTS}

The authors gratefully acknowledge the financial support of Ministry of Education and Science of Ukraine under project number M 5487

The authors declare no competing interest.

\section{REFERENCES}

1. L. Wang, X. Zhang, B. Li, P. Sun, J. Yang, H. Xu, Y. Liu, ACS Appl. Mater. Interf. 3 No 4, 1277 (2011).

2. M. Shaban, F. Mohamed, S. Abdallah, Nanocatalyst. Sci. Rep. 8, 3925 (2018).

3. A. Verbič, M. Gorjanc, B. Simončič, Coatings 9 No 9, 550 (2019).
4. U.G.M. Ekanayake, N. Rathuwadu, M.M.M.G.P.G. Mantilaka, R.M.G. Rajapakse, RSC Adv. 8 No 55, 31406 (2018).

5. G.D. Patil, A.H. Patil, S.A. Jadhav, C.R. Patil, P.S. Patil, Mater. Lett. 255, 126562 (2019).

6. M. Ashraf, C. Campagne, A. Perwuelz, P. Champagne, A. Leriche, 
C. Courtois, J. Colloid Interf. Sci. 394, 545 (2013).

7. P.J. Rivero, A. Urrutia, J. Goicoechea, F.J. Arregui, Nanoscale Res. Lett. 10 No 501, 1 (2015).

8. L. Frunza, N. Preda, E. Matei, S. Frunza, C.P. Ganea, A.M. Vlaicu, L. Diamandescu, A. Dorogan, J. Polymer Sci. Part B: Polymer Phys. 51 No 19, 1427 (2013).

9. D.H. Kim, J.-H. Park, T.I. Lee, J.-M. Myoung, Sol. Energ. Mater. Sol. C. 150, 65 (2016).

10. D. Szyszka, Mining Sci. 135 No 42, 131 (2012).

11. S. Li, J. Huang, Z. Chen, G. Chen, Y. Lai, J. Mater. Chem. A 5 No 1,31 (2017).

12. S. Park, J. Kim, C.H. Park, J. Eng. Fiber. Fabric. 10 No 4 , 155892501501000 (2015).

13. N.P. Klochko, K.S. Klepikova, V.R. Kopach, I.I. Tyukhov, D.O. Zhadan, G.S. Khrypunov, S.I. Petrushenko, S.V. Dukarov, V.M. Lyubov, M.V. Kirichenko, A.L. Khrypunova, Sol. Energ. 171, 704 (2018)

14. N.P. Klochko, K.S. Klepikova, V.R. Kopach, G.S. Khrypunov, Yu.O. Myagchenko, E.E. Melnychuk, V.M. Lyubov, A.V. Kopach, Semiconductors 50 No 3, 352 (2016).

15. A.F. Abdulrahman, S.M. Ahmed, N.M. Ahmed, M.A. Almessiere, AIP Conf. Proc. 1875, 020004 (2017).
16. O.F. Farhat, M.M. Halim, N.M. Ahmed, M.A. Qaeed, Superlattice. Microstructure. 100, 1120 (2016).

17. The Structure and Physical Properties of Solids. Laboratory Manual: The School-Book (Ed. by L.S. Palatnik) (Kiev: Vishcha Shkola: 1983)

18. S.V. Tsybulya, S.V. Cherepanova, Introduction into Structural Analysis of Nanocrystals (Novosibirsk: Novosib. Gos. Univ.: 2008)

19. H.S. Sindhu, S. Joishy, B.V. Rajendra, A. Rao, M. Gaonkar, S.D. Kulkarni, P.D. Babu, Mater. Sci. Semiconductor Proc. 68, 97 (2017).

20. J. Wu, J. Xia, W. Lei, B. Wang, PLoS ONE, 5 No 12, e14475 (2010).

21. B. Cortese, D. Caschera, F. Federici, G.M. Ingo, G. Gigli, J. Mater. Chem. A 2 No 19, 6781 (2014).

22. J.T. Newberg, C. Goodwin, C. Arble, Y. Khalifa, J.A. Boscoboinik, S. Rani, J. Phys. Chem. B 122 No 2, 472 (2017).

23. J.A. Röhr, J. Sá, S.J. Konezny, Commun. Chem. 2 No 1, 52 (2019).

24. J.-W. Hu, S.-H. Yang, S.-C. Jeng, RSC Adv. 6 No 57, 52095 (2016).

25. J. Li, Q. Sun, S. Han, J. Wang, Z. Wang, C. Jin, Prog. Organ. Coat. 87, 155 (2015).

\title{
Змочуваність бавовняних і поліестерових тканин, покритих наноструктурованими шарами оксиду цинку, легованого індіем
}

\author{
Н.П. Клочко ${ }^{1}$, І.В. Хрипунова ${ }^{1}$, К.С. Клепікова ${ }^{1}$, В.Р. Копач${ }^{1}$ Д.О. Жадан ${ }^{1}$, С.І. Петрушенко르, \\ С.В. Дукаров ${ }^{2}$, В.М. Любов ${ }^{1}$, М.В. Кіріченко ${ }^{1}$, А.Л. Хрипунова ${ }^{1}$ \\ 1 Національний технічний університет "Харківський політехнічний інститут», вул. Кирпичова, 2, \\ 61002 Харків, Украйна \\ ${ }^{2}$ Харківський національний університет імені В.Н. Каразіна, 4, площа Свободи, 61022 Харків, Україна
}

Тонкі плівки легованого індіем оксиду цинку (ZnO:In) осаджувалися на тканини бавовни (Ct) і поліестеру (PET) методом послідовної адсорбції та реакції іонного шару (SILAR) з метою створення зру чного в носінні, нетоксичного, легкого, і повітропроникного текстилю. Таким чином, ми отримали матеріали з іерархічною мікро- та наномасштабною шорсткістю ZnO:In/Ct i ZnO:In/PET, відповідно. Отримані плівки ZnO:In мають однофазну нанозернисту полікристалічну гексагональну структуру типу вюрцит. Показано, що властива бавовні гідрофрільність забезпечуе змочуваність тканини $\mathrm{ZnO}: \mathrm{In} / \mathrm{Ct}$ як до, так і після вакуумного відпалу. Навпаки, тканина ZnO:In/PET гідрофообна, iї кут контакту з водою $C A$ дорівнюе $140^{\circ}$. Виявилося, що можна надати супергідрофобні властивості тканині $\mathrm{ZnO}: \mathrm{In} / \mathrm{PET}$ без будь-якого додаткового просочувального шару за допомогою вакуумного відпалу при $200{ }^{\circ} \mathrm{C}$ протягом 1 або 2 год. Супергідрофобність ціеї тканини була підтверджена як статичними, так 1 динамічними вимірами $C A=160^{\circ}$ та гістерезисом контактного кута $C A H=10^{\circ}$, відповідно. Стан змочування Кассі-Бакстера для відпаленої тканини ZnO:In/PET визначається за допомогою техніки випаровування крапель води. Під впливом ультрафіолетового (УФ) випромінювання (26 Вт, довжини хвиль в діапазоні 315-400 нм) протягом 60 хв відпалені у вакуумі тканини ZnO:In/PET перетворюються із супергідрофобних у гідрофобні, їх $C A$ зменшуються з $160^{\circ}$ до $\sim 130^{\circ}$ і повертаються через 9 днів зберігання в темряві. Таким чином, ми отримали супергідрофобну тканину, яка залишається незмочуваною в умовах експлуатації на сонячному світлі.

Ключові слова: Легований індієм оксид цинку, Супергідрофобність, Бавовна, Поліестер. 